\title{
Dopamine transporter, gender, and number of sexual partners among young adults
}

\author{
Guang Guo*,1, Yuying Tong ${ }^{1}$, Cui-Wei $\mathrm{Xie}^{2}$ and Leslie A Lange ${ }^{3}$
}

\author{
${ }^{1}$ Department of Sociology, University of North Carolina, Chapel Hill, NC, USA; ${ }^{2}$ Department of Psychiatry and \\ Biobehavioral Sciences, Semel Institute for Neuroscience and Human Behavior, University of California, Los Angeles, \\ CA, USA; ${ }^{3}$ Department of Genetics, University of North Carolina, Chapel Hill, NC, USA
}

The dopamine transporter gene (DAT1) codes for a dopamine transporter protein, which limits the level and duration of dopamine receptor activation. The DAT1 gene is a strong candidate gene for rewardseeking behavior. This article reports compelling evidence for the association between the 40 bp variable number of tandem repeats in the DAT1 gene and the self-reported number of sexual partners among young adults in the United States using the sibling subsample of more than $\mathbf{2 5 0 0}$ individuals who participated in the National Longitudinal Study of Adolescent Health. We performed tests of genotypegender interaction as well as analyses stratified by gender. Among the males, possessing one or two alleles of the 10 repeat is associated with an $80-100 \%$ increase $(P<0.0001,2 \mathrm{df})$ in the number of sexual partners as compared with the homozygotes for the 9 repeat. The association holds in race/ethnicity-stratified analyses, in Allison's procedure that tests population stratification, and in within-family fixed-effects models. Covariate adjustment for a standard set of socioeconomic factors including religiosity, family structure, parental education, marital and cohabitation history, and neighborhood poverty did not attenuate these associations. Discussion is provided why this finding is absent among females. European Journal of Human Genetics (2007) 15, 279-287. doi:10.1038/sj.ejhg.5201763; published online 24 January 2007

Keywords: DAT1; dopamine transporter; number of sexual partners; sexual behavior; gene-gender interaction; behavior genetics

\section{Introduction}

Although many young adults delay marriage or other forms of long-term commitment, they have more sexual partners than any other age group. ${ }^{1,2}$ The number of sexual partners youth have is an important indicator of the risk of contracting a sexually transmitted disease (STD), including HIV. $^{3,4}$ Of estimated 12 million of new STD infections that occur each year in the US, three million occur among people younger than 20 , and another four million occur among those aged between 20 and $25 .^{5}$

*Correspondence: Professor G Guo, Department of Sociology, University of North Carolina, CB\#3210, Chapel Hill, NC 27599-3210, USA.

Tel: + 19199 621246; Fax: + 19199 627568;

E-mail: guang guo@unc.edu

Received 23 May 2006; revised 20 November 2006; accepted 21 November 2006; published online 24 January 2007
Both animal and human studies have demonstrated a genetic basis for sexual behavior. A twin study based on 1600 female twin pairs reported that approximately $40 \%$ of the variance in the self-reported number of sexual partners can be attributed to genetic factors. ${ }^{6}$ Studies on humans indicate that the stimulation of dopamine receptors would enhance male sexual behavior and that the inhibition of them would impair male sexual behavior. ${ }^{7}$ Pharmacological experiments using animal models have also shown that increased dopamine activity boosts male sexual activity. ${ }^{7}$

The soluble carrier family six dopamine transporter member three gene (DAT, locus symbol: SLC6A3) codes for a dopamine transporter protein (DAT), which limits the level and duration of dopamine receptor activation. ${ }^{8}$ The mouse model of dopamine transporter gene knockout established not only the central importance of dopamine 
transporter in controlling synaptic dopamine levels, but also its role as an obligatory target for the behavioral and biochemical action of amphetamine and cocaine. ${ }^{9}$ Vandenbergh et al $^{10}$ identified several polymorphisms in DAT1, including a polymorphic $40 \mathrm{bp}$ repeat in the transcribed portion of the gene, which is most commonly observed repeat $9\left(D A T 1^{*} 9 \mathrm{R}\right)$ to 10 times $\left(D A T 1^{*} 10 \mathrm{R}\right)$. One study found that humans homozygous for the 10R allele exhibited significantly lower dopamine transporter binding than carriers of the $9 \mathrm{R}$ allele, ${ }^{11}$ although the findings from another study are inconsistent. ${ }^{12}$

Intense interest has been directed at understanding the role of the dopamine transporter gene in the neurotransmission process because of its involvement in several behaviors. A number of studies have demonstrated an association between the $10 \mathrm{R}$ allele in the DAT1 gene and attention deficit hyperactivity disorder. ${ }^{13-17}$ The $D A T 1^{\star} 9 \mathrm{R}$ allele was reported to be associated with both a lower score in novelty seeking and a greater success in smoking cessation, ${ }^{18}$ cocaine-induced paranoia, ${ }^{19}$ and an increased risk for delirium and seizures during withdrawal in alcoholics. $^{20,21}$ Although no study seems to have focused on the DAT1 variants and number of sexual partners, the link is plausible because of the central role of dopamine in motor activity and reward-seeking behavior.

Gender is a crucial factor to be considered in studies of number of sexual partners. Males of most mammalian species show a strong desire towards variety in sexual partners. In the laboratory, this phenomenon has been referred to as the 'Coolidge effect'. ${ }^{22-24}$ It was first observed among rats. The same effect is even more striking in farm animals such as sheep and cattle. ${ }^{25}$ Studies based on self-reports among human subjects found that partner variety is of greater interest to male adolescents, ${ }^{26}$ male college students ${ }^{27}$ and male adults ${ }^{28-32}$ than their female counterparts.

Two broad theoretical approaches have been developed to explain the gender differences in number of sexual partners or, more generally, reproductive strategies: the evolutionary theory and the social control of human sexuality. The evolutionary theory argues that the differences in the relative costs and benefits of sexual behaviors between the two genders over the evolutionary process have produced the gender differences in mating predispositions. ${ }^{33-38}$ For females, every copulation might have led to conception, followed by lengthy periods of childbearing and child-rearing; having more sexual partners did not increase female fitness. Thus, females who selected fewer sexual partners with ability and willingness to contribute parental resources tended to place successfully offspring in succeeding generations. As a result, female traits related to mating choosiness were selected by evolution and were passed onto the present human populations. In contrast, males could increase their reproductive success by increasing the number of sexual partners because they were not contributing similar resources and time.

Social theories have emphasized social regulation of human sexuality as a source for gender differences in sexual behavior. ${ }^{39,40}$ Religion and family have historically been important institutions for regulating sexuality in Western society. Social theories argue that the gender differences are at least partially due to double sexual standards because men traditionally enjoy more power than women in virtually all the major institutions: politics, religion, economics, and family. Male sexual activity is tolerated and even encouraged, whereas the female sexual activity is more controlled and subject to censure of violation of norms. Because of the changes in gender role attitudes and the general understanding of male and female sexuality in recent decades, sexual standards have become more permissive and more egalitarian between the two genders.

The present study has three objectives. The first is to investigate the association between the $40 \mathrm{bp}$ variable number of tandem repeats (VNTR) in the DAT1 gene and the self-reported number of sexual partners among young adults using the DNA sample of about 2500 individuals in the National Longitudinal Study of Adolescent Health (Add Health). The second objective aims at testing the interaction between the DAT1 variants and gender for the number of sexual partners. Lastly, we re-estimate the association after taking into account of a social science model of sexual behavior including religiosity, family structure, parental education, marital and cohabitation history, neighborhood poverty, and health behavior such as alcohol use and illegal drug use.

\section{Materials and methods Subject}

The data source for our analysis is the sibling subsample of about 2500 participants in the Add Health, a nationally representative sample of more than 20000 adolescents in grades 7-12 in 1994-1995 in the United States. ${ }^{41}$ Add Health is longitudinal; the respondents have since been followed by two additional in-home interviews in 19951996 (Wave II) and 2002 (Wave III).

In Wave III in 2002, DNA samples were collected from a subset of the Add Health sample. The subset consists of a total of 2597 participants including MZ twins (186 pairs), same-sex DZ twins (136 pairs), opposite-sex DZ twins (103 pairs), full biological siblings (569 pairs), and singletons.

\section{Measures}

Number of sexual partners At Wave III, the respondents aged 19-26 were asked the question: 'With how many partners have you ever had vaginal intercourse, even if only once?' To protect confidentiality, reduce nonresponses and increase reporting accuracy, this section of the interview was self-administered by audio-CASI 
(computer-assisted self-interview). The sensitive question was read to respondents by means of audio headphones. Respondents were given instructions on how to complete their answers on the computer. The technique has been shown to reduce the disparity between men and women in the number of sex partners reported. ${ }^{42}$ Table 1 gives the mean reported number of sexual partners and standard deviation by ethnicity, age group, and gender.

As in every other survey on number of sexual partners, ${ }^{43}$ the number of female partners reported by males exceeds the number of male partners reported by females in Add Health. The overall male-to-female ratio in Add Health is about 1.3. Because a heterosexual intercourse involves a male and a female, in a closed population, the total number of copulations for males must be the same as those for females; the total number of sexual partners for males must also be the same as those for females. Two hypotheses have been proposed to explain the higher reported maleto-female ratio: (1) Males over-report and (2) most females have fewer partners than most males, but a few females have a very large number of partners. Brewer et al ${ }^{44}$ tested the second hypothesis using data from national sex studies of prostitutes and their clients in the United States. They found an under-representation of prostitute women in these national surveys. Once the under-representation and their large numbers of sexual partners are factored in, the male-female disparity disappears.

DNA preparation and genotyping At Wave III in 2002, in collaboration with the Institute for Behavioral Genetics in Boulder, CO, Add Health collected, extracted, and quantified DNA samples from the sibling subsample. Genomic DNA was isolated from buccal cells using a modification of published methods. ${ }^{45-48}$ All the methods employed Applied Biosystems instruments and reagents. Microsatellite and VNTR polymorphisms were performed using fluorescent primers that were analyzed on an ABI capillary electrophoresis instrument. Single nucleotide polymorphisms were analyzed using an ABI Sequence Detection System and 5'nuclease (Taqman ${ }^{\circledR}$ ) methodology.

A $40 \mathrm{bp}$ VNTR polymorphism in the $3^{\prime}$ untranslated region of the DAT1 gene has been genotyped with a modified method of Vandenbergh et al. ${ }^{49}$ The VNTR ranges from 3 to 11 copies with the 9-repeat (9R) and 10-repeat (10R) polymorphisms being the two most common alleles in Caucasian, Hispanic and African-American populations. ${ }^{50}$ In our analysis sample, the $9 \mathrm{R}$ and $10 \mathrm{R}$ account for about 21 and $76 \%$ of all alleles, respectively; 35, 59, and $0.048 \%$ of the respondents possess one $10 \mathrm{R}$, two 10Rs, and two 9Rs, respectively (Table 2 ). The variation across ethnic groups appears to be moderate with the 10R allele accounts for $80,86,80$, and $90 \%$ of all alleles in whites, blacks, Hispanics, Asians, respectively. A series of $\chi^{2}$ tests for the polymorphism and for each self-reported ethnic group (European, African-American, Hispanic, and Asian) reveals no deviation from the Hardy-Weinberg equilibrium.

Table 2 Descriptive statistics

\begin{tabular}{|c|c|c|c|}
\hline & Mean & & Mean \\
\hline \multicolumn{2}{|l|}{ Allele proportion } & \multicolumn{2}{|l|}{ Family structure } \\
\hline $10 R(480)$ & 0.76 & Two biological parents & 0.613 \\
\hline $9 \mathrm{R}(440)$ & 0.21 & Single parent & 0.220 \\
\hline Others & 0.022 & Step parent & 0.132 \\
\hline \multicolumn{4}{|l|}{ Genotype proportion } \\
\hline One 10R (480) & 0.35 & \multicolumn{2}{|l|}{ Marriage/cohabitation } \\
\hline Two 10R (480) & 0.59 & Single & 0.523 \\
\hline Two 9R (440) & 0.048 & Cohabited and married & 0.091 \\
\hline Others & 0.012 & Married, not & 0.099 \\
\hline Female & 0.522 & $\begin{array}{l}\text { cohabitation } \\
\text { Cohabit, not married }\end{array}$ & 0.282 \\
\hline \multicolumn{2}{|l|}{ Race/ethnicity } & \multicolumn{2}{|l|}{ Parental education } \\
\hline White & 0.571 & High school & 0.277 \\
\hline Asian & 0.073 & $<$ High school & 0.112 \\
\hline Black & 0.184 & Some college & 0.201 \\
\hline \multirow{2}{*}{$\begin{array}{l}\text { Hispanic } \\
\text { Other }\end{array}$} & 0.146 & $\geq$ College & 0.361 \\
\hline & 0.026 & \multicolumn{2}{|l|}{ Neighborhood poverty } \\
\hline Church attendance & & $<11.6 \%$ & 0.556 \\
\hline Weekly or more & 0.209 & $\begin{array}{l}11.6-23.9 \% \\
>23.9 \%\end{array}$ & $\begin{array}{l}0.191 \\
0.183\end{array}$ \\
\hline Never & 0.253 & & 0.183 \\
\hline $\begin{array}{l}\text { Less than once/ } \\
\text { month }\end{array}$ & 0.373 & & \\
\hline Less than weekly & 0.160 & & \\
\hline
\end{tabular}

No. of persons $2552 \quad 2552$

Table 1 Mean number of sexual partners and SD by age group, gender, and ethnicity

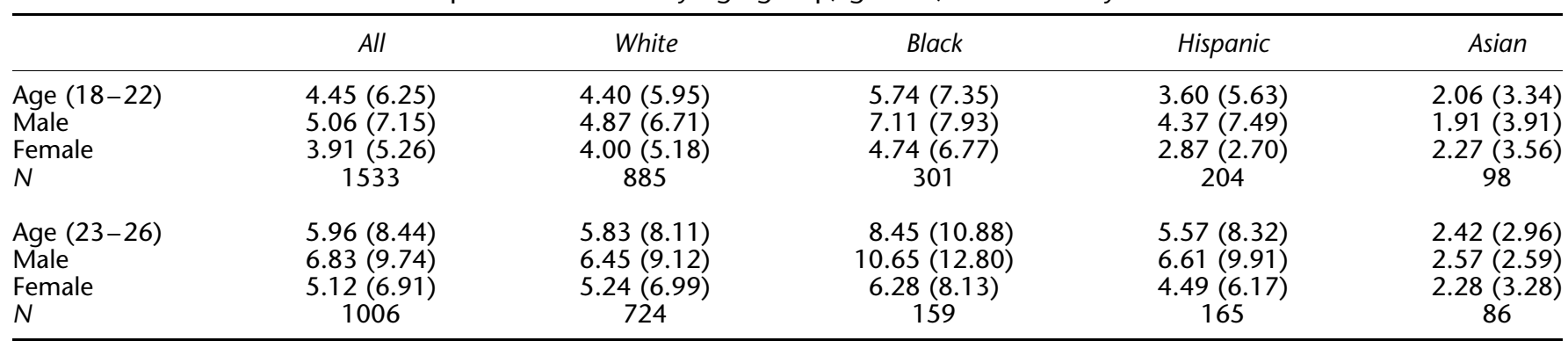


Socioeconomic measures Table 2 also provides the descriptive statistics for socioeconomic and other nongenetic factors used in the analysis. Church attendance measures attendance frequency with categories of never, less than once/month, less than weekly, and weekly or more. Family structure is a variable of four categories: twobiological-parent families, single-parent families, stepparent families, and other types of families including families with adopted and foster children. One's marital and cohabitation history may be related to the number of sexual partners. Our marriage/cohabitation includes categories of being single, having cohabited and have been married, having been only married, and having only cohabited. Parental education also has four categories: less than high school, high school graduation, some college, and at least a college degree. Add Health measured the level of education from both the mother and the father of a respondent. We used the higher of the two when both were available. Poverty at the neighborhood level is measured by the proportion of families living below the official poverty line in a Census block group, which is the smallest geographic area for which the Census Bureau publishes sample data. In 1990, block groups averaged 452 housing units or 1100 individuals. The block groups are divided into low-poverty, median-poverty, and high-poverty categories. The two cutoff points for the three categories are 11.6 (the median proportion of families in a block group living below the poverty line) and $23.9 \%$ (the 75 th percentile of the proportion of families in a block group living below the poverty line).

\section{Analytical strategies}

To test the association between the DAT1 variants and the number of sexual partners, a three-step analytical strategy was adopted. The first step was an exploratory data analysis that compares the mean count of partners across genotypes, stratified by gender and age group. In the second step, we estimated a number of generalized estimating equations (GEE) Poisson regression models ${ }^{51}$ that adjust for the correlation among siblings in the data and allow covariate adjustment for factors such as gender, race/ ethnicity, and a set of social environmental factors. The third step addresses potential bias from population stratification.

The rest of this section elaborates on the second and third steps. Step 2 uses the Poisson regression model,

$$
\begin{aligned}
E\left(Y_{i j} \mid x_{i j}\right)= & \exp \left(\beta_{0}+\beta_{1} D A T 1_{i j}+\beta_{2} \text { race }_{i j}\right. \\
& \left.+\beta_{3} \text { female }_{i j}+\ldots\right),
\end{aligned}
$$

where $E\left(Y_{i j} \mid x_{i j}\right)$ is the expected number of partners for individual $i$ in sibling cluster $j$ given the individual's characteristics $x_{i j}$ and $D A T 1_{i j}$ represents the genetic variants for the individual. The exposure was explicitly adjusted by age (not shown in equation; see Table 4). To account for the dependence among the siblings in the Add Health data, we estimated the model using the GEE, ${ }^{51}$ which has long been established in the statistical literature as a standard approach for addressing correlated data. The GEE models were implemented using SAS. In addition, we performed gender-stratified analysis, in which we estimated Equation (1) twice, each time using only the male or female sample.

We used four strategies to address the potential impact of population structure. First, we adjusted for self-reported race/ethnicity in all regression analysis so that the comparisons across genotypes are made after adjusting for any main effect of race/ethnicity. Second, we estimated the genotype effect in a white male sample and a black male sample separately. As a third strategy, we applied the Allison et al's ${ }^{52}$ procedure to test for possible population stratification. The procedure is based on the reasoning that the probabilities of genotypes of siblings depended entirely on parental genotypes and that controlling for the genotype effects of sibship would be equivalent to controlling for parental genotypes. This model could be considered as a special case of the mixed model. ${ }^{53,54}$ Our last strategy is a stringent within-family fixed-effect model that has been used widely to account for unobserved effects at the family level. ${ }^{55}$

\section{Results \\ Genotypic mean count by gender and age}

Table 3 shows the number of sexual partners by genotype, gender, and age. Among the males, the 10R appears to be associated with higher number of sexual partners. In the younger group of 18-22 years, possessing one or two copies of 10R approximately doubles the number of partners. In the older group of 23-26 years, possessing one or two copies of 10R increases the number of partners from about 4-7. Age is positively related to the number of partners; but there does not seem be an interaction between age and the effect of the DAT1 variants, that is, the effect of DAT1 does not seem to vary across the life stages of adolescence and young adulthood. Among the females, the 10R allele does not seem to be associated with higher number of sexual partners. This is the case in both age groups, suggesting an interaction between DAT1 and gender. Because of the sibling clustering in the data,

Table 3 Mean number of sexual partners (sample size) by genotype, gender, and age group

\begin{tabular}{lcccc}
\hline & Age group & $9 R / 9 R$ & $9 R / 10 R$ & $10 R / 10 R$ \\
\hline Male & $18-23$ & $2.42(33)$ & $4.92(243)$ & $5.29(415)$ \\
& $23-26$ & $4.08(25)$ & $6.85(158)$ & $7.07(289)$ \\
\multirow{4}{*}{ Female } & $18-23$ & $4.12(42)$ & $4.44(263)$ & $3.56(481)$ \\
& $23-26$ & $4.60(20)$ & $5.80(164)$ & $4.60(317)$ \\
\hline
\end{tabular}


standard significance tests are not valid for these comparisons. The next section presents significance tests for the main effects of DAT1 and the interactive effects of DAT1 and gender obtained from the GEE regression models.

\section{Regression analysis}

Table 4 reports the results from the GEE Poisson models that adjust for the correlation among the siblings in our sample. Using the combined sample of males and females, Model 1 estimates the main effects of the DAT1 polymorphism and gender after controlling for race/ethnicity. According to Model 1, those with the DAT1*10R/10R genotype reported $32 \%(P=0.038$, CI $(1.02,1.72))$ more sexual partners than the $D A T 1^{*} 9 \mathrm{R} / 9 \mathrm{R}$ genotypes; those with the $D A T 1^{\star} 10 \mathrm{R} / 9 \mathrm{R}$ genotype reported $39 \%(P=0.018$, CI $(1.06,1.84))$ more partners. These results apply to both males and females. The model has also adjusted for age groups.

We also estimated a gene-gender interaction model (data not shown) that adds to the first model the interaction terms between genotype and gender. The model indicates that the association of the 10R allele of DAT1 only applies to males. Among the males, the 10R/10R genotype raises the number of partners by $93 \%$ relative to the 9R/9R genotype; similarly, the 10R/9R raises the number of partners by $83 \%$. The genotype effect does not

Table 4 GEE Poisson models of number of sexual partners

\begin{tabular}{|c|c|c|c|c|c|c|}
\hline \multirow{3}{*}{$\begin{array}{l}\text { Sample } \rightarrow \\
\text { Predictors } \downarrow\end{array}$} & \multicolumn{2}{|c|}{ Models without social controls } & \multicolumn{4}{|c|}{ Models with social controls } \\
\hline & \multirow{2}{*}{\multicolumn{2}{|c|}{$\beta \quad$ All }} & \multicolumn{2}{|c|}{ Male } & \multicolumn{2}{|c|}{ Female } \\
\hline & & & $\mathrm{e}^{\beta}$ & P-value & $\mathrm{e}^{\beta}$ & P-value \\
\hline Intercept & 5.261 & $<0.0001$ & 1.835 & 0.0119 & 2.851 & $<0.0001$ \\
\hline 9R/9R & - & - & - & - & - & - \\
\hline $10 \mathrm{R} / 10 \mathrm{R}$ & 1.320 & 0.0381 & 1.899 & 0.0002 & 0.942 & 0.7071 \\
\hline 10R/9R & 1.395 & 0.0189 & 1.785 & 0.0015 & 1.147 & 0.4196 \\
\hline Other/other & 1.575 & 0.0175 & 1.680 & 0.0419 & 1.434 & 0.1462 \\
\hline Female & 0.781 & $<0.0001$ & & & & \\
\hline Age $(24-26)$ & - & — & - & - & - & - \\
\hline Age $(18-20)$ & 0.594 & $<0.0001$ & 0.655 & 0.0009 & 0.636 & 0.0005 \\
\hline Age $(21-23)$ & 0.792 & 0.0016 & 0.772 & 0.0142 & 0.818 & 0.0449 \\
\hline White & - & - & - & - & - & - \\
\hline Asian & 0.439 & $<0.0001$ & 0.426 & $<0.0001$ & 0.555 & 0.0008 \\
\hline Black & 1.392 & $<0.0001$ & 1.699 & $<0.0001$ & 1.313 & 0.0266 \\
\hline Hispanic & 0.886 & 0.2034 & 1.044 & 0.7645 & 0.851 & 0.2036 \\
\hline \multicolumn{7}{|l|}{ Family structure } \\
\hline Two biological parents & & & - & - & - & - \\
\hline Single parent & & & 1.080 & 0.4948 & 1.245 & 0.0187 \\
\hline Step parent & & & 1.285 & 0.0382 & 1.356 & 0.0159 \\
\hline \multicolumn{7}{|l|}{ Parent education } \\
\hline High school & & & - & - & - & - \\
\hline$<$ High school & & & 0.903 & 0.4943 & 0.961 & 0.7518 \\
\hline Some college & & & 1.231 & 0.0845 & 1.226 & 0.0267 \\
\hline$\geq$ College & & & 0.979 & 0.8428 & 1.195 & 0.0728 \\
\hline \multicolumn{7}{|l|}{ Neighborhood poverty } \\
\hline$<11.6 \%$ & & & — & — & — & - \\
\hline $11.6-23.9 \%$ & & & 0.792 & 0.0295 & 0.867 & 0.1604 \\
\hline$\geq 23.9$ & & & 0.807 & 0.079 & 0.865 & 0.2935 \\
\hline \multicolumn{7}{|l|}{ Marriage/cohabitation } \\
\hline Single & & & - & - & - & — \\
\hline Cohabit and married & & & 1.450 & 0.0077 & 1.148 & 0.233 \\
\hline Married, not cohabitation & & & 0.895 & 0.4634 & 0.813 & 0.0962 \\
\hline Cohabit, not married & & & 1.590 & $<0.0001$ & 1.380 & 0.0002 \\
\hline \multicolumn{7}{|l|}{ Church attendance } \\
\hline Weekly or more & & & - & - & - & - \\
\hline Never & & & 1.814 & $<0.0001$ & 1.660 & $<0.0001$ \\
\hline Less than once/month & & & 1.832 & $<0.0001$ & 1.520 & $<0.0001$ \\
\hline Less than weekly & & & 1.727 & $<0.0001$ & 1.342 & 0.0183 \\
\hline No. of persons & & & & & & \\
\hline $\log L$ & & & & & & \\
\hline
\end{tabular}


exist among the females. The gene-gender interaction model is highly significant over Model 1 by the likelihood ratio test $\left(\chi^{2}=37\right.$ with $\left.3 \mathrm{df}\right)$.

Table 4 also presents the results of the gene-gender interaction estimated by stratifying the sample by gender. We estimated two such models one for males and one for females without adjusting for social control variables (data not shown). In the male model, the $D A T 1 * 10 \mathrm{R} / 10 \mathrm{R}$ genotype is associated with a $100 \%(P=0.001, \mathrm{CI}$ $(1.32,3.03))$ increase in the reported number of sexual partners relative to the $D A T 1^{*} 9 \mathrm{R} / 9 \mathrm{R}$ genotype; the corresponding increase for the $D A T 1^{*} 10 \mathrm{R} / 9 \mathrm{R}$ genotype is $88 \%(P=0.005$, CI $(1.21,2.92))$. In the female model, the genotypes do not seem to be related to the number of partners $(P=0.53$ and 0.57 , respectively). The second and third models in Table 4 re-estimated these results after including a set of socioeconomic factors: church attendance, family structure, parental education, marital and cohabitation history, and neighborhood poverty. The association between the genotype and the number of partners continues to be absent among the females. Among the males, the two genotypes of 10R/10R and 10R/ 9R raise the number of partners by $90 \% \quad(P=0.0002$, CI $(1.36,2.66))$ and $79 \%(P=0.0015, \mathrm{CI}(1.25,2.55))$, respectively.

The effects of socioeconomic factors are generally consistent with expectations. Having a step-parent or single-parent relative to having two-biological parents, having a cohabitation history, and especially attending church service less than weekly relative to weekly or more tend to be associated with a higher number of sexual partners. Having some college education (but not having at least a college degree) relative to just a high school education is associated with a higher number of partners.

Our final model - the male model with the social controls in Table 4 - was tested for robustness through the addition of illegal drug use and alcohol use. Previous work reported a substantial correlation between number of sexual partners and risky behaviors. ${ }^{57}$ Both illegal drug use (any illegal drug use at Wave III) and alcohol use (frequency over past year at Wave III) are positively and significantly related to number of partners; however, our key findings have remained unchanged with the adjustment of the two risky behaviors (data not shown). For example, with the adjustment, the $\exp (\beta)$ s for $10 \mathrm{R} / 10 \mathrm{R}$ and 10R/9R are $1.87(P=0.0001)$ and $1.76(P=0.0008)$, respectively, as compared with $1.89(P=0.0002)$ and 1.78 $(P=0.001)$, respectively, estimated without the adjustment.

To address the potential biases from population stratification, we carried out the four strategies described earlier. First, race/ethnicity was included as a control in all regression models estimated (Table 4). Second, we have further stratified our male sample by race/ethnicity. Our main results hold within both the white and black samples;

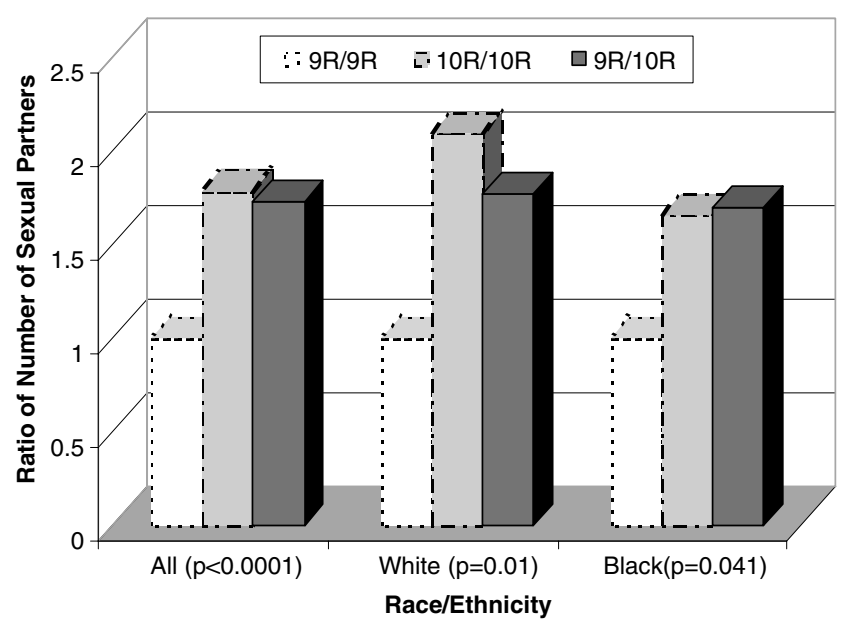

Figure 1 Ratios of number of sexual partners by genetype based on regression results.

the estimated effect sizes of DAT1 have remained similar to those based on the ethnicity-combined models, but the $P$-values are smaller as expected (Figure 1). We carried out Allison's procedure ${ }^{52}$ that includes three random parameters: one random effect at the sibling level, a second random effect at the individual level, and a third random parameter designed to capture the interaction between the genotype across sibling clusters and the observed DAT1 variants. We estimated this model using the mixed or multilevel model because the Poisson random effect model with more than one random effect depends on approximations and often yields highly biased results. ${ }^{58}$ The included random interaction term from the Allison's procedure is highly significant with $P<0.0001$. The $D A T 1^{*} A n y 10 \mathrm{R}$ is associated with 2.6 more sexual partners $(P=0.0016$, CI $(1.03,4.14))$ than the $9 \mathrm{R} / 9 \mathrm{R}$ genotype (data not shown), which is consistent with the results from the Poisson models in Table 4 . We performed the within-family fixedeffect linear regression using 237 pairs of male DZ twins and full biological siblings in the DNA sample. Compared with $9 \mathrm{R} / 9 \mathrm{R}$, the $10 \mathrm{R} / 10 \mathrm{R}$ and $10 \mathrm{R} / 9 \mathrm{R}$ genotypes reported $5.69(P=0.049)$ and $5.05(P=0.066)$ more sexual partners, respectively.

Figure 1 summarizes the main findings by graphing the ratios of number of sexual partners by genotype. The three sets of bars are based upon the combined genetic and social-science model of all ethnicities, the white sample and the black sample. The $P$-values are based upon a likelihood ratio test that compares the model with genotype and the model without genotype using two degrees of freedom. The $D A T 1^{*} 9 \mathrm{R} / 9 \mathrm{R}$ is the reference category and its value is set as one. The association between DAT1 and number of sexual partners is evident in each of the three samples. 


\section{Discussion}

Very few studies seem to have examined the link between the genetic variants in the dopaminergic system and human sexual behavior. Miller et $a l^{59}$ reported a positive association between the presence of the 2 allele of $D R D 2$ and age at first sex in a sample of 414 middle-class nonHispanic European American men and women. Two recent studies, also based on Add Health, examined age at first sex and self-reported number of sexual partners over the past 12 months, respectively. ${ }^{60-61}$ The former found a link with a DRD4 variant in the white, Hispanic and Asian samples. The latter reported an association with a DRD2 variant and a 5HTT-religiosity interaction. The DAT1 gene was not related to number of sex partners over the past 12 months in the latter study. The present study reported an association between the $40 \mathrm{bp}$ VNTR in the DAT1 gene and lifetime number of sexual partners. It is likely that the short- and long-term numbers of sexual partners are not subject to the same set of genetic and environmental factors. The model with social control for the males in Table 4 in the present study yielded an $R^{2}$ of 0.126 indicating that a large portion of the variance remains unexplained. Some other polymorphisms within DAT1 and other genes may also contribute to our lifetime measure of number of partners.

Evidence for the differences between males and females in sexual behavior was reported from animal studies. The neurotransmitter dopamine has been shown to facilitate male sexual behavior in all investigated species including rodents and humans. ${ }^{7}$ Melis and Argiolas' ${ }^{62}$ findings suggest a major role for dopaminergic receptors in both the preparatory and consummatory phase of male sexual behavior, whereas their role in female sexual behavior is less conclusive. Hull et $a l^{63}$ discussed three mechanisms through which males sexual behavior is affected by dopamine among rats: dopamine increases male sexual arousal and courtship behavior, enhances the motor acts of mounting behavior, and facilitates genital response to stimulation.

We researched for evidence that may explain the sex differences in our findings via the twin and full-sib data in Add Health and biometrical methods. Table 5 gives the twin and sibling intraclass correlations and number of pairs by gender and type of sibling pairs using the mixed models. ${ }^{56}$ Heritability of number of sex partners was estimated to be 0.50 for females and 0.38 for males. The estimates were obtained after controlling for age and ethnicity. Partly because the numbers of pairs available were moderate, we were unable to show that the two estimates are statistically different from one another. Overall, the biometrical data do not offer a clear answer to the question of whether a sex-specific genetic component is present, which is suggested by the analysis of DAT1 variants.

We briefly outlined two theoretical perspectives earlier in this article to interpret the gene-gender interaction or the absence of the effect of DAT1 among females. The evolutionary argument is based on the vast physiological differences in the reproductive system between males and females. Because of the differences, partner variety only increases the male fitness and not the female one. The argument hypothesizes that the evolutionary process has selected gender-specific physiological basis for partner variety. The male-to-female ratio of self-reported partners in our sample is consistent with the evolutionary argument; however, the DAT1 gene is unlikely to be part of the gender-specific basis because of its presence in both genders. Nevertheless, it is possible that the genderspecific system interacts with DAT1 and suppresses its ramifications for partner variety among females. The perspective of social control of human sexuality predicts a stronger societal control for females than males. The stronger social regulation of female sexuality could lessen or completely suppress the potential impact of the DAT1 gene on partner variety. Our findings of genegender interaction are thus consistent with both the evolutionary and the social control arguments, but this study is unable to produce evidence to disprove one in favor of the other.

A gene-gender interaction shares similarities with a geneenvironment interaction. A gene-gender interaction can be a gene-environment interaction as suggested by the social control argument, a gene-gene interaction as suggested by the evolutionary argument or simultaneously a geneenvironment interaction and a gene-gene interaction.

The DAT1 gene is unlikely to be a 'sex' gene itself. As suggested earlier in this article, the more likely scenario is that the gene is associated with a predisposition for a number of related behaviors, of which sexual partner variety is one. The gene may have a moderate effect on certain behaviors and may interact with environment to exert such an effect, that is, whether the genetic predisposition leads to the behavior may often depend on environmental conditions.

Table 5 Sibling intraclass correlations (number of pairs) of number of reported sexual partners by gender and zygosity

\begin{tabular}{lccccc}
\hline Pair type & MZF & MZM & DZF & DZM & DZOS \\
Correlation & $0.38(94)$ & $0.45(92)$ & $0.13(63)$ & $0.28(73)$ & $0.17(103)$ \\
\hline $\begin{array}{l}\text { Pair type } \\
\text { Correlation }\end{array}$ & - & - & Fullsib-F & Fullsib-M & Fullsib-OS \\
\hline
\end{tabular}


In summary, our data have provided consistent evidence for the association between the $40 \mathrm{bp}$ VNTR polymorphism in the DAT1 gene and self-reported number of sexual partners using a sample of more than 2500 youth. Among the male young adults, possessing one or two alleles of the $10 \mathrm{R}$ is associated an $80-100 \%$ increase in the number of partners as compared with those possessing two alleles of the 9R. This finding is not evident among females. An equivalent interpretation can treat one or two 10Rs as the 'wild type', which amounts to about $91 \%$ of the individuals in the sample. Then the homozygotes for $9 \mathrm{R}$ can be considered as the 'conservative' or 'undaring' type whose reported number of sexual partners is about one half of the number reported by the wild type.

\section{Acknowledgements}

This research uses data from Add Health, a program project designed by J Richard Udry, Peter S Bearman, and Kathleen Mullan Harris, and funded by a grant P01-HD31921 from the National Institute of Child Health and Human Development, with cooperative funding from 17 other agencies (www.cpc.unc.edu/addhealth/contract.html). Special acknowledgment is due to Andrew Smolen and John K Hewitt of the Institute for Behavior Genetics, University of Colorado for DNA isolation and genotyping. We express our appreciation for the comments made by anonymous reviewers. We gratefully acknowledge supports from NIH, P01-HD31921 to Add Health; RO3 HD04249002 and R03 HD053385-01 to Guang Guo; from NSF, SES -0210389 to Guang Guo.

\section{References}

1 Santelli JS, Brener ND, Lowry R, Bhatt A, Zabin LS: Multiple sexual partners among US adolescents and young adults. Fam Plann Perspect 1998; 30: 271-275.

2 Forrest JD, Singh S: The sexual and reproductive behavior of American women, 1982-1988. Fam Plann Perspect 1990; 22: $206-$ 214

3 Kost K, Forrest JD: American women's sexual behavior and exposure to risk of sexually transmitted diseases. Fam Plann Perspect 1992; 24: 244-254.

4 Cates W, Stone KM: Family planning, sexually transmitted diseases and contraceptive choice: a literature update - part 1 . Fam Plann Persp 1992; 24: 75-84.

5 Kassler WJ, Cates WJ: The epidemiology and prevention of sexually transmitted diseases. Urol Clin North Am 1992; 19: 1-12.

6 Cherkas LF, Oelsner EC, Mak YT et al: Genetic influences on female infidelity and number of sexual partners in humans: a linkage and association study of the role of the vasopressin receptor gene (AVPR1A). Twin Res 2004; 7: 649-658.

7 Dominguez JM, Hull EM: Dopamine, the medial preoptic area, and male sexualbehavior. Physiol Behav 2005; 86: 356-368.

8 Bannon MJ, Brownschidle LA, Tian Y et al: Neurokinin-3 receptors modulate dopamine cell function and alter the effects of 6hydroxy dopamine. Brain Res 1995; 695: 19-24.

9 Giros B, Jaber M, Jones SR, Wightman RM, Caron MG: Hyperlocomotion and indifference to cocaine and amphetamine in mice lacking the dopamine transporter. Nature 1996; 379: 606-612.

10 Vandenbergh DJ, Perisco AM, Hawkins AL et al: Human dopamine transporter gene (DAT1) maps to chromosome 5p15.3 and displays a VNTR. Genomics 1992; 14: 1104-1106.
11 Jacobsen LK, Staley JK, Zoghbi SS et al: Prediction of dopamine transporter binding availability by genotype: a preliminary report. Am J Psychiatry 2000; 157: 1700-1703.

12 Heinz A, Goldman D, Jones DW et al: Genotype influences in vivo dopamine transporter availability in human striatum. Neuropsychopharmacology 2000; 22: 133-139.

13 Cook EH, Stein MA, Krasowski MD et al: Association of attention deficit disorder and the dopamine transporter gene. Am J Hum Genet 1995; 56: 993-998.

14 Daly G, Hawi Z, Fitzgerald M, Gill M: Mapping susceptibility loci in attention deficit hyperactivity disorder: preferential transmission of parental alleles at DAT1, DBH and DRD5 to affected children. Mol Psychiatry 1999; 4: 192-196.

15 Gill M, Daly G, Heron S, Hawi Z, Fitzgerald M: Confirmation of association between attention deficit hyperactivity disorder and a dopamine transporter polymorphism. Mol Psychiatry 1997; 2: 311-313.

16 Waldman ID, Rowe DC, Abramowitz A et al: Association and linkage of the dopamine transporter gene and attention-deficit hyperactivity disorder in children: Heterogeneity owing to diagnostic subtype and severity. Am J Hum Genet 1998; 63: $1767-1776$.

17 Cornish KM: Association of the dopamine transporter (DAT1) 10/ 10-repeat genotype with ADHD symptoms and response inhibition in a general population sample. Mol Psychiatry 2005; 10: 686-698.

18 Sabol SZ, Nelson ML, Fisher CD et al: A genetic association for cigarette smoking behavior. Health Psychol 1999; 18: 7-13.

19 Gelernter J, Kranzler HR, Satel SL, Rao PA: Genetic association between dopamine transporter protein alleles and cocaineinduced paranoia. Neuropsychopharmacology 1994; 11: 195-200.

20 Sander T, Harms H, Podschus J et al: Allelic association of a dopamine transporter gene polymorphism in alcohol dependence with withdrawal seizures or delirium. Biol Psychiatry 1997; 41: 299-304.

21 Schmidt LG, Harms H, Kuhn S, Rommelspacher H, Sander T: Modification of alcohol withdrawal by the A9 allele of the dopamine transporter gene. Am J Psychiatry 1998; 155: 474-478.

22 Wilson JR, Kahn RE, Beach FA: Modification in the sexual behavior of male rats produced by changing the stimulus female. J Comp Physiol Psychiatry 1963; 56: 636-644.

23 Bermant G, Lott DF, Anderson L: Temporal characteristics of the Coolidge effect in male rat copulatory behavior. J Comp Physiol Psychiatry 1966; 65: 447-452.

24 Bermant G: Sexual behaviour: hard times with the Coolidge Effect; in Siegel MH, Zeigler HP (eds): Phychological research: the inside story. New York: Harper \& Row, 1976, pp. 76-103.

25 Wilson G: The great sex divide. Peter Owen (London) 1989; ScottTownsend (Washington, DC) 1992, pp 41-45.

26 Small SA, Silverburg SB, Kerns D: Adolescents' perceptions of the costs and benefits of engaging in health-compromising behaviors. J Youth Adolesc 1993; 22: 73-87.

27 Clark RD, Hatfield E: Gender differences in receptivity to sexual offers. J PsycholHum Sex 1989; 2: 39-55.

28 McBurney DH, Zapp DJ, Streeter SA: Preferred number of sexual partners: tails of distributions and tales of mating systems. Evol Hum Behav 2005; 26: 271-278.

29 Buss DM, Schmitt DP: Sexual strategies theory: an evolutionary perspective on human mating. Psychol Rev 1993; 100: 204-232.

30 Carroll JL, Volk KD, Hyde JS: Differences between males and females in motives for engaging in sexual intercourse. Arch Sex Behav 1985; 14: 131-139.

31 Simpson JA, Gangestad SW: Individual differences in sociosexuality: evidence for convergent and discriminant validity. J Personality Soc Psychol 1991; 60: 870-883.

32 Oliver MB, Hyde JS: Gender differences in sexuality: a meta analysis. Psychol Bull 1993; 114: 29-51.

33 Williams GC: Adaptation and Natural Selection: A Critique of Some Current Evolutionary Thought. Princeton, NJ: Princeton University Press, 1966. 
34 Geary DC: Male, Female: The Evolution of Human Sex Differences. Washington, DC: American Psychological Association, 1998.

35 Hrdy SB: The Woman that Never Evolved. Cambridge, MA: Harvard University Press, 1981.

36 Symons D: The Evolution of Human Sexuality. New York: Oxford University Press, 1979.

37 Trivers RL: Parental investment and sexual selection; in Campbell B (ed): Sexual Selection and the Decent and Man. Chicago: Aldine, 1972, pp 136-179.

38 Maynard SJ: The Evolution of Sex. New York: Cambridge University Press, 1977.

39 DeLamater J: The social control of sexuality;. Annu Rev Sociol 1981; 81: 263-290.

40 DeLamater J: The social control of human sexuality; in Mckinney $\mathrm{K}$, Specher S (eds): Human Sexuality: The Societal and Interpersonal Context. Norwood, NJ: Ablex Publishing Corporation, 1989, pp 30-62.

41 Harris KM, Florey F, Tabor J, Bearman PS, Jones J, Udry JR: The National Longitudinal Study of Adolescent Health: Research design [WWW document]. Retrieved June 10, 2005 from http:// www.cpc.unc.edu/projects/addhealth/design.

42 Tourangeau R, Smith TW: Asking sensitive questions: the impact of data collection mode, question format, and question context. Public Opin Quarte 1996; 60: 275-304.

43 Smith TW: Discrepancies between men and women in reporting number of sexual partners: a summary from four countries. Soc Biol 1992; 39: 203-211.

44 Brewer DD, Potterat JJ, Garrett SG et al: Prostitution and the sex discrepancy in reported number of sex partners. Proc Natl Acad Sci USA 2000; 97: 12385-12388.

45 Lench N, Stanier P, Williamson R: Simple non-invasive method to obtain DNA for gene analysis. Lancet 1988; 1: 1356-1358.

46 Meulenbelt I, Droog S, Trommelen GJ, Boomsma DI, Slagboom PE: High-yield noninvasive human genomic DNA isolation method for genetic studies in geographically dispersed families and populations. Am J Hum Genet 1995; 57: $1252-1254$.

47 Spitz E, Moutier R, Reed T et al: Comparative diagnoses of twin zygosity by SSLP variant analysis, questionnaire, and dermatoglyphic analysis. Behav Genet 1996; 26: 55-64.

48 Freeman B, Powell J, Ball D, Hill L, Craig I, Plowmin R: DNA by mail: an inexpensive and noninvasive method for collecting DNA samples from widely dispersed populations. Behav Genet 1997; 27: 251-257.

49 Vandenbergh DJ, Rodriguez LA, Miller IT, Uhl GR, Lachman HM: High-activity catechol-O-methyltransferase allele is more prevalent in polysubstance abusers. Am J Hum Genet 1992; 74: 439-442.

50 Doucette-Stamm LA, Blakey DJ, Tian J, Mockus S, Mao JI: Population genetic study of human dopamine transporter gene (DAT1). Genet Epidemiol 1995; 12: 303-308.

51 Liang KY, Zeger SL: Longitudinal data analysis using generalized linear models. Biometrika 1986; 73: 13-22.

52 Allison DB, Heo M, Kaplan N, Martin ER: Development of siblingbased tests of linkage in the presence of association for quantitative traits that do not require parental information. Am J Hum Genet 1999; 64: 1754-1764.

53 Searle SR: Linear Models. New York: Wiley, 1971.

54 Searle SR, Casella G, McCulloch C: Variance Components. New York: Wiley, 1992.

55 Guo G, VanWey LK: Sibship size and intellectual development: is the relationship causal? Am Sociol Rev 1999; 64: 169-187.

56 Guo G, Wang J: The mixed or multilevel model for behavior genetic analysis. Behav Genet 2002; 32: 37-49.

57 Miles DR, van den Bree MBM, Gupman AE, Newlin DB, Glantz MD, Pickens RW: A twin study on sensation seeking, risk taking behavior and marijuana use. Drug Alcohol Depen 2001; 62: 57-68.

58 Rodriguez G, Goldman N: An assessment of estimation procedures for multilevel models with binary responses. J R Stat Soc Ser A (Stat Soc) 1995; 158: 73-89.

59 Miller WB, Pasta DJ, Macmurray J, Chiu C, Wu H, Comings DE: Dopamine receptors are associated with age at first sexual intercourse. J Biosoc Sci 1999; 31: 43-54.

60 Guo G, Tong Y: Age at first sexual intercourse, genes, and social \& demographic context: evidence from twins and the dopamine D4 receptor gene. Demography 2006; 43: 747-769.

61 Halpern CT, Kaestle CE, Guo G, Hallfors DD: Gene-environment contributions to young adult sexual partnering. Arch Sex Behav 2006, Published online on 21 December 2006; DOI 10.1007/ S10508-006-9084-9.

62 Melis MR, Argiolas A: Dopamine and sexual behavior. Neurosci Biobehav Rev 1995; 19: 19-38.

63 Hull E, Meisel R, Sachs BD: Male sexual behavior; in Pfaff EW, Arnold A, Etgen A, Fahrbach S, Rubin R (eds): Hormones, Brain and Behavior, San Diego: Academic Press/Elsevier, 2002, pp 1-139. 